\title{
Diamonds and inclusions from the Jagersfontein kimberlite
}

\author{
I. L. Chinn', H. J. Milledge ${ }^{2}$, and J. J. Gurney ${ }^{1}$
}

1: Dept of Geological Sciences, University of Cape Town, Rondebosch, 7700, South Africa

2: Dept of Geological Science, University College London, Gower St, WC1E 6BT, United Kingdom

Previous investigation of 28 diamonds from the Jagersfontein kimberlite (Rickard et al., 1991) indicated the presence of polymineralic websteritic "micro-nodule" inclusions of garnet, clino- and ortho-pyroxene. Another unusual feature of Jagersfontein diamonds is the presence of majoritic garnets which are believed to have crystallized at extreme pressures. The peridotitic paragenesis is characterized by olivines with elevated $\mathrm{Cr}$ and $\mathrm{Ca}$ contents, and a single olivine inclusion with a low Fo content of 78.8 was designated as websteritic.

Infrared and microprobe studies of ten Jagersfontein diamonds with polished windows indicate the presence of $\mathrm{CO}_{2}$ and small inclusions of native iron, orthopyroxene, phlogopite and $\mathrm{SiO}_{2}$ (Beard and Milledge, 1988). Further study of the inclusions, carbon isotope compositions and Infrared absorption characteristics of 70 unpolished diamonds from Jagersfontein was undertaken in order to obtain a better understanding of asthenospheric diamond growth regions and the relative importance of harzburgitic, lherzolitic, eclogitic and websteritic assemblages as diamond source lithologies at this locality. Diamonds were cracked to liberate inclusions, and hence those containing $\mathrm{CO}_{2}$ and abundant micro-inclusions such as those described by Beard and Milledge (1998) were not cracked for inclusion recovery.

The nitrogen content of $60 \%$ of the diamonds studied was below the detection level of the FTIR spectrometer, and hence these diamonds are classified as Type II. The spectra of three of these Type II diamonds contain absorption peaks due to the presence of $\mathrm{CO}_{2}$. One of the $\mathrm{CO}_{2}$-bearing diamonds contained two sulphide inclusions which have reequilibrated from the initial MSS to pyrrhotite, minor chalcopyite and pentlandite. Sulphide inclusions were recovered from another Type Ia diamond.

The highest nitrogen content of 5412 at. ppm was measured in a diamond with variable nitrogen content, as indicated by a second spectrum consistent with $3275 \mathrm{ppm}$ nitrogen. Variation in $\mathrm{N}$ was detected in other diamonds and it is thought that nitrogen-free Type II growth zones may be intergrown with the Type Ia zones. This would result in unrealistically high estimates of mantle residence temperatures and times from the nitrogen content and aggregation state as discussed by Chinn et al. (1998). Assuming a time-averaged mantle residence temperature of $1200{ }^{\circ} \mathrm{C}$, six diamonds yield mantle residence times considerably greater than the age of the earth. Multiple spectra of all six of these, and several other diamonds suggest the presence of Type II or nitrogenpoor zones within the diamonds.

Micro-nodules of garnet and pyroxene were recovered from three diamonds, and majoritic garnets were present in four diamonds, all of which are notable for their extremely low nitrogen contents. Majorite coexisted with an eclogitic garnet lacking evidence of clinopyroxene solid solution in one of these diamonds. A further five diamonds contained eclogitic garnets. Ilmenite inclusions in diamonds are rare, except for eclogitic diamonds from the George Creek kimberlite in Colorado (Chinn, 1995) where about a third of the garnet inclusions recovered contained small inclusions of 
ilmenite. However, ilmenite appears to have been relatively abundant in the Jagersfontein eclogitic diamond growth region as two diamonds contained ilmenite inclusions. The ilmenites coexisted with eclogitic clinopyroxene in one case and eclogitic garnet and a micro-nodule in the other.

Peridotitic inclusions were recovered from two Type Ia diamonds which contained olivine and chromite. The two olivine inclusions exhibit typical inclusion compositions with Fo contents of 93. However, the eclogitic paragenesis is dominant amongst Jagersfontein diamonds and this is consistent with the presence of $\mathrm{CO}_{2}$-bearing diamonds as is the case for the State Line District of Colorado (see Chinn et al., 1998)

\section{References}

Beard, A.D., and Milledge, H.J. 1998, Infrared and Microprobe Studies of intrusions and microinclusions in diamond. Seventh Int. Kimberlite Conf., Cape Town, Ext. Abstr.

Chinn, I.L. 1995, A study of unusual diamonds from the George Creek K1 kimberlite dyke, Colorado. Unpubl. $\mathrm{PhD}$ thesis, University of Cape Town.

Chinn, I.L., Gurney, J.J, Milledge, H.J., Taylor, W.R. and Woods, P.A. 1995, Cathodoluminescence properties of $\mathrm{CO}_{2}$-bearing and $\mathrm{CO}_{2}$-free diamonds from the George Creek $\mathrm{K} 1$ kimberlite dike. Intl. Geol. Rev., 37, p. 254-258.

Chinn, I.L., McCallum, M.E., Harris, C., Milledge, H.J., and Gurney, J.J. 1998, CO 2 -bearing diamonds in eclogite xenoliths from the Sloan 2 kimberlite, Colorado. Seventh Int. Kimberlite Conf., Cape Town, Ext. Abstr.

Rickard, R.S., Gurney, J.J. and Harris, J.W. 1991, Mineral inclusions in diamonds from Jagersfontein mine. Fifth Int. Kimberlite Conf., Araxa, Ext. Abstr: p. 336-338. 